\title{
Model Suasana Kelas yang Mensejahterakan Siswa Tingkat Pendidikan Dasar
}

\author{
Rahmat Aziz ${ }^{(1)}$, Nur Ahmad Hardoyo Sidik ${ }^{(2)}$ Trimansyah $^{(3)}$, Nur Khasanah ${ }^{(4)}$, Nurul Mahruzah Yulia ${ }^{(5)}$ \\ ${ }^{(1)}$ Fakultas Psikologi Universitas Islam Negeri Maulana Malik Ibrahim Malang \\ (2),(3),(4),(5) Program Pascasarjana Universitas Islam Negeri Maulana Malik Ibrahim Malang
}

\begin{abstract}
The students' well-being is an educational issue that has recently received great attention from various parties, be they academicians, politicians, and policymakers. This research aimed to test the role of classroom climate in enhancing students' well-being. A correlational study in our work revealed that overall, among a sample of 300 grade V and grade VI students in elementary schools and madrasah ibtidaiyah in East Java, classroom climate positively and significantly predicted students' well-being. The classroom climate promoted students' wellbeing particularly when it took shape via task orientation and when it encouraged solidarity, cooperation, and involvement among students, as well as the perceived teacher justice. Aspects of classroom climate which were suboptimal in explaining students' well-being included teacher support and learning inquiry.
\end{abstract}

Keywords: class climate model, primary school, students' well-being

Kesejahteraan siswa baru-baru ini merupakan isu pendidikan yang mendapat perhatian serius dari berbagai pihak, baik akademisi, politisi, maupun pembuat kebijakan. Penelitian ini bertujuan untuk menguji sejauh mana suasana kelas berperan dalam meningkatkan kesejahteraan siswa. Subjek penelitian adalah 300 siswa kelas V dan VI sekolah dasar dan madrasah ibtidaiyah yang ada di Jawa Timur. Studi korelasional dalam penelitian ini menunjukkan bahwa secara keseluruhan, suasana kelas menjadi prediktor positif yang signifikan bagi tingkat kesejahteraan siswa. Suasana kelas yang secara signifikan berpengaruh terhadap kesejahteraan siswa adalah suasana kelas yang berorientasi pada tugas, yang bisa mendorong kekompakkan, kerjasama, dan keterlibatan antar siswa, serta yang meningkatkan persepsi bahwa guru telah memperlakukan siswa secara adil. Aspek suasana kelas yang tidak secara signifikan berpengaruh terhadap kesejahteraan siswa mencakup dukungan guru terhadap siswa dan proses penyelidikan dalam kelas.

Kata kunci: kesejahteraan siswa, model suasana kelas, sekolah dasar

MEDIAPSI, 2020, Vol. 6(2), 94-101, DOI: https://doi.org/10.21776/ub.mps.2020.006.02.3

Received: 27-11-2019. Revised: 04-08-2020. Accepted: 16-09-2020. Published online: 07-12-2020

Handling Editor: Intan Rahmawati, Universitas Brawijaya, Malang, Indonesia

*Corresponding author: Rahmat Aziz, Fakultas Psikologi Universitas Islam Negeri Maulana Malik Ibrahim Malang,

Indonesia. E-mail: azira@uin-malang.ac.id

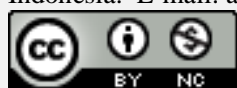

This work is licensed under a Creative Commons Attribution-NonCommercial 4.0 International License.

How to cite this article in accordance with the American Psychological Association (APA) $6^{\text {th }}$ guidelines:

Aziz, R., Sidik, N. A. H., Trimansyah, Khasanah, N., \& Yulia, N. M. (2020). Model suasana kelas yang mensejahterakan siswa tingkat pendidikan dasar. MEDIAPSI, 6(2), 94-101. https://doi.org/10.21776/ub.mps.2020.006.02.3

\section{Pendahuluan}

Kajian tentang kesejahteraan siswa barubaru ini mendapat perhatian besar terutama dalam bidang pendidikan. Setidaknya ada tiga alasan mengapa kajian tentang kesejahteraan menjadi penting. Pertama, ada pergeseran paradigma di dunia pendidikan, yang menyatakan bahwa keberhasilan akademik 
anak-anak tidak lagi hanya terkait dengan intelektual tetapi juga menekankan pentingnya aspek kesejahteraan psikologis. Kedua, anakanak berada dalam tahap perkembangan sehingga mereka memiliki potensi untuk mengalami kegagalan dalam menjalankan tugas perkembangannya, yang berakibat pada rendahnya tingkat kesejahteraan psikologis mereka (de Carvalho \& Skipper, 2019). Ketiga, beberapa anak masih mengalami kekerasan dalam proses pendidikan di sekolah (O'BrienRichardson, 2019).

Menurut Kirkcaldy (2015), kajian tentang kesejahteraan psikologis sangat penting. Argumentasinya, tingginya tingkat kesejahteraan berkaitan dengan peningkatan kesehatan, kebahagiaan, kebermaknaan hidup, usia, kesuksesan karier, kualitas hubungan sosial, dan fungsi kognitif (Kirkcaldy, 2015). Beberapa penelitian memfokuskan kajiannya pada hubungan antara kesejahteraan dengan kesehatan fisik dan mental serta perannya dalam masalah pembangunan sosial dan ekonomi (Boehm, Peterson, Kivimaki, \& Kubzansky, 2011). Penelitian lain menemukan bahwa kesejahteraan memprediksi umur panjang di antara populasi sehat (Steptoe, O’Donnell, Marmot, \& Wardle, 2008).

Di tingkat internasional, kesadaran mengenai pentingnya kesehatan atau promosi kesejahteraan di sekolah telah menjadi program penting Organisasi Kesehatan Dunia (WHO). Menurut organisasi ini, definisi kesehatan adalah kesejahteraan fisik, mental, sosial, dan emosional yang sehat, tidak hanya menghindari seseorang dari penyakit. Pada tahun 1992, WHO wilayah Eropa menciptakan proyek untuk peningkatan program kesehatan mental di sekolah-sekolah yang disebut European Network of Health Promoting School yang merupakan salah satu program peningkatan kesejahteraan emosional siswa sosial di sekolah (Konu \& Rimpella, 2002). Data empiris tentang kesejahteraan psikologis pada siswa dapat dilihat dari hasil penelitian yang menunjukkan bahwa tingkat kesejahteraan psikologis siswa hanya berada pada kategori sedang (Prabowo, 2016). Temuan Penelitian menarik lainnya adalah persepsi positif oleh siswa di Yogyakarta dalam memandang suasana sekolah dimana mereka berada (Khatimah, 2015). Lingkungan sekolah yang dimaksud adalah keseluruhan kondisi yang ada di sekolah yang dialami para anggota, baik yang bersifat fisik maupun sosial dan suasana tersebut mempengaruhi perilaku mereka.

Istilah kesejahteraan (well-being) sering digunakan, baik dalam kebijakan dan literatur akademik, secara bergantian dengan istilah kesehatan mental yang positif. Secara historis, pemahaman tentang kesejahteraan telah menjadi perdebatan yang sangat panjang terutama terkait dengan dua pandangan: hedonis dan eudemonik (Tennant dkk., 2007). Perbedaan dua pandangan ini telah dijelaskan oleh Ryan (2009) dimana kesejahteraan hedonis berfokus pada keadaan kesenangan dan kebahagiaan, sedangkan kesejahteraan eudemonik berfokus pada aktualisasi potensi manusia. Lebih jelas lagi Keyes (2013) menjelaskan bahwa tradisi hedonis berfokus pada kepedulian manusia dengan memaksimalkan durasi perasaan positif atau menyenangkan sambil meminimalkan durasi perasaan menyakitkan atau tidak menyenangkan. Berbeda dengan hedonis, eudemonik adalah tradisi yang berfokus pada kepedulian sosial dengan mengembangkan kemampuan dan kapasitas baru untuk menjadi orang yang berfungsi sepenuhnya.

Banyak faktor yang diduga memengaruhi kesejahteraan psikologis siswa, yang diantaranya adalah keluarga. Penelitian menemukan bahwa hubungan sesama anggota keluarga dengan kesejahteraan siswa adalah sangat erat dan tidak dapat dipisahkan. Karena itu, hubungan yang harmonis antar anggota keluarga dapat mengembangkan tingkat kesejahteraan anggotanya (Salomone dkk., 2018). Penelitian lain menemukan bahwa kurangnya keseimbangan dalam keluarga memengaruhi tingkat depresi dan kesejahteraan 
yang buruk pada seorang anak (Haar, 2014). Hasil serupa ditemukan oleh Krauss, Seltzer, dan Jacobson (2005), yang mengungkap bahwa pengalaman positif dan negatif ibu mempengaruhi kehidupan anggota keluarga mereka. Beberapa hasil penelitian di atas menunjukkan bahwa keluarga adalah faktor penting yang dapat mempengaruhi kesejahteraan siswa.

Selain faktor fungsi keluarga, lingkungan sekolah juga diduga menjadi salah satu variabel yang dapat mempengaruhi tingkat kesejahteraan siswa. Penelitian menunjukkan bahwa suasana sekolah terkait dengan kesejahteraan mental dan emosional siswa. Artinya, lingkungan sekolah yang kondusif dapat menjadi solusi dan strategi dalam upaya pengembangan kesejahteraan siswanya (Lester \& Cross, 2015). Suasana sekolah yang dimaksud tidak dapat dilepaskan dengan istilah suasana kelas. Suasana kelas secara umum diartikan sebagai kondisi perasaan seseorang tentang pengalamannya di kelas dan sekolah baik secara fisik maupun psikologis. Lebih jauh lagi, Powell dan Graham (2017) menyarankan sebuah pendekatan untuk mendukung program kesejahteraan siswa di sekolah dengan cara membuat kebijakan yang ditandai oleh wacana untuk memahami konsep kesejahteraan yang lebih baik dan yang mampu menciptakan fasilitas sekolah yang memadai untuk pengembangannya.

Beberapa hasil penelitian yang telah dikemukakan di atas menunjukkan bahwa sekolah mempunyai peran yang sangat penting dan strategis dalam memberikan kontribusi bagi peningkatan atau penurunan kesejahteraan siswa. Sekolah juga diyakini sebagai salah satu agen penting yang dapat membantu mengatasi masalah-masalah mendasar di masyarakat, menciptakan masyarakat yang kuat, serta mempersiapkan remaja sebagai warga negara yang berkualitas (Weare, 2000). Lingkungan sekolah yang dimaksud dalam penelitian ini adalah suasana kelas tempat berlangsungnya proses belajar dan pembelajaran. Kerangka konseptual dalam Gambar 1 di bawah ini memperjelas alur pemikiran dalam penelitian ini.

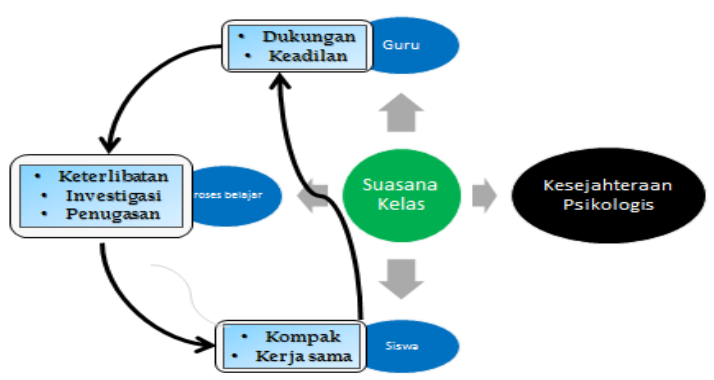

Gambar 1. Kerangka konseptual penelitian tentang kesejahteraan psikologis siswa

Mengacu pada Gambar 1 di atas, kesejahteraan psikologis dapat dikembangkan dengan menciptakan suasana kelas yang kondusif, yang ditandai dengan adanya 1) perilaku guru yang mendukung dan berbuat adil terhadap siswa, 2) perilaku siswa yang kompak dan saling bekerjasama dalam belajar, dan 3) proses belajar dalam kelas yang membuat siswa merasa nyaman untuk terlibat, menekankan proses penyelidikan, dan yang berorientasi pada tugas. Kondisi kelas seperti itulah yang diduga akan mampu mengembangkan kesejahteraan siswa di sekolah. Berdasarkan uraian di atas, tujuan penelitian ini adalah untuk mendeskripsikan tentang kesejahteraan siswa dan untuk menguji model suasana kelas yang mampu mengembangkan kesejahteraan siswa.

\section{Metode}

\section{Partisipan dan desain penelitian}

Partisipan dalam penelitian ini adalah 300 siswa (139 Laki-laki, 161 perempuan) kelas $\mathrm{V}$ dan VI sekolah dasar dan madrasah ibtidaiyah di empat kota di Jawa Timur, yaitu Malang, Blitar, Jombang, dan Pasuruan. Penelitian ini dirancang sebagai penelitian kuantitatif korelasional yang bertujuan menguji peran suasana kelas sebagai variabel independen terhadap kesejahteraan siswa sebagai variabel dependen. 


\section{Prosedur dan pengukuran}

Penelitian ini diadministrasikan di dalam kelas untuk menyebarkan skala kepada partisipan. Skala tersebut terdiri dari, pertama, suasana kelas. Suasana kelas didefinisikan sebagai kondisi yang terjadi di dalam kelas baik berupa perilaku guru, perilaku siswa, maupun proses yang terjadi dalam pembelajaran. Suasana kelas diukur meggunakan skala What is Happening in this Class? (WIHIC). Skala WIHIC telah dikembangkan oleh Fraser, McRobbie, dan Fisher (1996) dan telah divalidasi oleh Dorman (2008). Skala ini terdiri dari beberapa aspek, yang meliputi 1) kekompakkan (contoh aitem; "Saya berteman dengan siswa di kelas ini"), 2) kolaborasi siswa (contoh aitem; "Saya berkolaborasi dengan orang lain ketika melakukan tugas"), 3) dukungan guru (contoh aitem; "Guru tertarik dengan masalah saya"), 4) keadilan guru (contoh aitem; "Saya mendapat jumlah bantuan yang sama dari guru seperti murid lainnya"), 5) keterlibatan di kelas (contoh aitem; "Saya memberikan pendapat saya selama diskusi kelas"), 6) investigasi pembelajaran (contoh aitem: "Saya melakukan investigasi untuk menjawab pertanyaan guru"), dan 7) orientasi tugas (contoh aitem: "Saya tahu apa yang saya coba capai di kelas ini"). Skala ini memiliki reliabilitas Cronbach Alpha $(\alpha)$ yang memadai untuk tiap tiap aspeknya, yang bervariasi dari .75 sampai dengan .94 (MacLeod \& Fraser, 2010).

Sementara itu, kesejahteraan siswa diukur dengan skala kesejahteraan mental WarwickEdinburgh. Skala ini digunakan untuk mengukur kesejahteraan mental dengan bertanya pada peserta seberapa sering mereka merasa optimis tentang masa depan, merasa bermanfaat, merasa santai, menangani masalah dengan baik, berpikir jernih, merasa dekat dengan orang lain, mampu memutuskan sendiri tentang hal-hal selama dua minggu terakhir. Opsi jawabam bergerak dari 1 sampai dengan 5 pada skala Likert (Stewart-Brown \&
Janmohamed, 2008). Skala ini telah diuji dalam penelitian sebelumnya dan memiliki reliabilitas yang memuaskan $(\alpha=.92)$ (Taggart dkk., 2013).

\section{Hasil}

Untuk menguji hipotesis dalam penelitian ini, data dianalisis menggunakan regresi berganda, baik secara simultan maupun parsial. Analisis simultan dilakukan untuk menguji peran semua aspek suasana kelas secara agregat terhadap kesejahteraan psikologis siswa. Analisis parsial digunakan untuk menguji peran masing-masing aspek suasana kelas terhadap kesejahteraan siswa.

Hasil analisis regresi berganda menunjukkan bahwa secara simultan, aspekaspek suasana kelas berperan signifikan dalam menjelaskan kesejahteraan siswa, $R=.62, p<$ .001). Nilai adjusted $R^{2}$ adalah sebesar .37. Hal ini berarti bahwa suasana kelas mampu menjelaskan tinggi rendahnya kesejahteraan siswa sebesar $37 \%$.

Selanjutnya, hasil analisis parsial ditampilkan dalam Tabel 1. Sebagaimana bisa dicermati pada Tabel 1, hasil analisis parsial menunjukkan bahwa di antara tujuh aspek suasana kelas, dukungan guru dan investigasi pembelajaran tidak berperan signifikan dalam menjelaskan kesejahteraan siswa.

Tabel 1. Hasil Analisis Parsial Peran Aspek-Aspek Suasana Kelas terhadap Kesejahteraan Siswa

\begin{tabular}{lccc}
\hline \multicolumn{1}{c}{ Variabel } & $M$ & $S D$ & Kesejahteraan \\
\hline Kesejahteraan & 59.70 & 7.29 & - \\
\hline Dukungan guru & 31.98 & 4.79 & $.08^{n s}$ \\
\hline Keadilan guru & 34.23 & 5.57 & $.14^{*}$ \\
\hline $\begin{array}{l}\text { Keterlibatan di } \\
\text { kelas }\end{array}$ & 30.33 & 5.31 & $.16^{*}$ \\
\hline $\begin{array}{l}\text { Investigasi } \\
\text { pembelajaran }\end{array}$ & 26.67 & 6.70 & $.09^{n s}$ \\
\hline $\begin{array}{l}\text { Orientasi tugas } \\
\text { Kekompakkan }\end{array}$ & 34.85 & 4.62 & $.21^{* *}$ \\
\hline $\begin{array}{l}\text { Kolaborasi siswa } \\
\text { Keterangan: } M=\text { rata-rata, } S D=\text { deviasi standar; } * p<.05, \text { * }^{*} p<.01,\end{array}$ \\
ns
\end{tabular}

${ }^{n s}=$ tidak signifikan. 


\section{Diskusi}

Penelitian ini bertujuan untuk menguji peran suasana kelas dalam menjelaskan kesejahteraan atau well-being siswa sekolah dasar. Mendukung hipotesis yang diajukan, suasana kelas menjadi prediktor positif dan signifikan bagi kesejahteraan siswa. Analisis lebih lanjut menunjukkan bahwa aspek keadilan guru, keterlibatan di kelas, orientasi tugas, kekompakkan, dan orientasi tugas berperan signifikan dalam menjelaskan kesejahteraan siswa. Sementara itu, dukungan guru dan proses penyelidikan di dalam kelas adalah dua aspek suasana kelas yang tidak berperan signifikan dalam menjelaskan kesejahteraan siswa.

Temuan-temuan di atas sejalan dengan penelitian sebelumnya yang menyatakan bahwa suasana kelas merupakan salah satu faktor yang strategis dan penting untuk mengembangkan kesejahteraan siswa (Lester \& Cross, 2015; Soutter, Gilmore, \& O'Steen, 2010). Hal ini disebabkan karena salah satu tujuan dilaksanakannya program pendidikan di sekolah adalah selain untuk mengembangkan pengetahuan dan kepribadian, juga untuk mengembangkan kesejahteraan siswanya baik secara fisik maupun psikologis. Kesejahteraana siswa dengan demikian menjadi isu penting dalam dunia pendidikan. Cowie, Boardman, Dawkins, dan Jennifer (2004) menjelaskan adanya lima alasan mengapa kesejahteraan menjadi agenda penting dalam dunia pendidikan. Alasan-alasan tersebut mencakup, pertama, banyaknya waktu yang digunakan siswa di sekolah. Alasan kedua adalah adanya peningkatan masalah-masalah sosial dan emosional di kalangan siswa, sementara alasan ketiga adalah adanya bukti bahwa hubungan antara sesama siswa mampu menciptakan kesejahteraan. Alasan keempat adalah adanya peran penting pendidik dalam mengembangkan kesejahteraan siswanya, sementara alasan kelima adalah adanya bukti bahwa keberhasilan akademis akan dapat ditingkatkan jika institusi dapat meningkatkan kesejahteraan peserta didiknya.
Beberapa penelitian telah menunjukkan peran penting sekolah dalam mengembangkan kesejahteraan psikologis siswa. Siswa akan belajar lebih efektif jika mereka berada dalam keadaan bahagia atau sebaliknya, dan keberhasilan akademik akan membantu siswa untuk meningkatkan perasaan bahagia dan harga diri mereka (Soutter dkk., 2010). Hal ini berimplikasi bahwa tugas yang harus dilakukan sekolah adalah bagaimana menciptakan suasana sekolah yang mampu mengembangkan kesejahteraan siswanya. Dalam konteks siswa di Indonesia, penelitian menunjukkan bahwa kesejahteraan psikologis diprediksi oleh tingginya tingkat keterlibatan siswa di sekolah dan memprediksi tingginya tingkat prestasi belajar (Dariyo, 2018).

Hasil analisis parsial menunjukkan bahwa aspek suasana kelas yang berpengaruh terhadap kesejahteraan siswa terkait dengan hubungan dengan guru dan proses pembelajaran. Sementara itu, terkait dengan aspek dukungan guru yang tidak berpengaruh terhadap kesejahteraan siswa, hal ini adalah sebuah temuan yang menarik untuk dicermati lebih jauh. Penyebabnya adalah karena temuan tersebut berbeda dengan beberapa penelitian sebelumnya yang menemukan bahwa hubungan guru dan siswa adalah sangat penting, bahkan merupakan kebutuhan dasar dalam proses pembelajaran (Spilt, Koomen, \& Thijs, 2011). Penelitian lainnya menemukan bahwa perilaku interpersonal guru sangat berpengaruh terhadap kesejahteraan siswanya (Van Petegem, Aelterman, Van Keer, \& Rosseel, 2007). Namun demikian, peran guru tidak berarti kurang penting dalam konteks pengembangan kesejahteraan siswa, karena hasil penelitian ini juga menemukan bahwa keadilan yang dilakukan guru terhadap siswanya mampu menjadi prediktor bagi kesejahteraan siswa. Dengan demikian, dapat dikatakan bahwa dalam konteks kehidupan siswa di tingkat pendidikan dasar, keadilan guru yang dilakukan guru terhadap siswanya berperan lebih penting 
dibandingkan dengan dukungan guru dalam mengembangkan kesejahteraan siswa.

Temuan berikutnya dalam penelitian ini menunjukkan bahwa investigasi dalam proses pembelajaran tidak berpengaruh terhadap kesejahteraan siswa. Beberapa penelitian menemukan bahwa pembelajaran dengan investigasi merupakan model yang sangat penting dan menarik untuk dilakukan (Sellwood, 1991), termasuk dalam pembelajaran matematika (Mungure, 2017). Hal ini tidak berarti bahwa investigasi dalam pembelajaran tidak penting, tetapi tidak efektif dibandingkan dengan aspek-aspek suasana kelas lainnya dalam mengembangkan kesejahteraan siswa. Sementara itu, dalam konteks pengembangan kesejahteraan siswa di sekolah, Konu dan Rimpela (2002) mengajukan konsep tentang school well-being models yang menarik untuk dipertimbangkan. Menurut konsep ini, pengembangan kesejahteraan siswa dikonseptualisasikan sebagai fenomena empat dimensi. Di satu sisi, kesejahteraan atau wellbeing dikaitkan dengan pengajaran dan pendidikan. Di sisi lain, kesejahteraan dikaitkan dengan pembelajaran dan prestasi. Dalam hal ini, kesejahteraan siswa di sekolah sangat tergantung pada empat aspek, yaitu kondisi sekolah (having), hubungan sosial (loving), sarana untuk pemenuhan diri atau selffullfillment (being), dan status kesehatan yang dilihat sebagai gejala penyakit dan penyakit yang diderita siswa. Dalam hal ini, sarana pemenuhan diri (self-fullfillment) mencakup kemungkinan bagi setiap siswa untuk belajar sesuai dengan sumber daya dan kemampuannya sendiri. Setiap aspek kesejahteraan mengandung beberapa aspek kehidupan murid di sekolah.

Penelitian ini memiliki beberapa kekurangan, yang bisa diperbaiki dalam studistudi lanjutan. Salah satu kekurangan terkait dengan peran investigasi pembelajaran dan dukungan guru sebagai aspek suasana kelas yang tidak signifikan dalam menjelaskan kesejahteraan siswa. Untuk mengklarifikasi lebih lanjut temuan tersebut, studi lanjutan bisa memasukkan variabel moderator yang berpotensi mempengaruhi arah dan besaran peran investigasi pembelajaran dan dukungan guru dalam memprediksi kesejahteraan siswa. Sebagai contoh, penelitian Chirkov dan Ryan (2001) menemukan bahwa dukungan guru, terutama yang menekankan otonomi siswa, berperan signfiikan dalam meningkatkan kesejahteraan siswa.

\section{Daftar Pustaka}

Boehm, J. K., Peterson, C., Kivimaki, M., \& Kubzansky, L. (2011). A prospective study of positive psychological wellbeing and coronary heart disease. Health Psychology, 30(3), 259-267. https://doi.org/10.1037/ a0023124

Chirkov, V. I., \& Ryan, R. M. (2001). Parent and teacher autonomy-support in Russian and US adolescents: Common effects on well-being and academic motivation. Journal of Cross-Cultural Psychology, 32(5), 618-635. https://doi.org/10.1177\%2F00220221010 32005006

Cowie, H., Boardman, C., Dawkins, J., \& Jennifer, D. (2004). Emotional health and well-being: A practical guide for schools. London: SAGE Publications

Dariyo, A. (2018). Peran school well being dan keterlibatan akademik dengan prestasi belajar pada siswa sekolah dasar. Journal Psikogenesis, $5(1)$. https://doi.org/10.24854/ jps.v5i1.490

de Carvalho, E., \& Skipper, Y. (2019). "We're not just sat at home in our pyjamas!": A thematic analysis of the social lives of home educated adolescents in the UK. European Journal of Psychology of Education, 34(3), 501-516. https://doi.org/10.1007/s10212-018-03985

Dorman, J. P. (2008). Use of multitraitmultimethod modelling to validate actual and preferred forms of the What Is 
Happening In this Class? (WIHIC) questionnaire. Learning Environments Research, 11(3), 179-193. https://doi.org/10.1007/s10984-008-90436

Fraser, B. J., McRobbie, C. J., \& Fisher, D. L. (1996, April). Development, validation and use of personal and class forms of a new classroom environment instrument. Paper presented at the annual meeting of the American Educational Research Association, New York, USA.

Haar, J. M., Russo, M., Suñe, A., \& OllierMalaterre, A. (2014). Outcomes of worklife balance on job satisfaction, life satisfaction and mental health: A study across seven cultures. Journal of Vocational Behavior, 85(3), 361-373. https://doi.org/10.1016/j.jvb.2014.08.010

Keyes, C. L. M. (2013). Promoting and protecting positive mental health: Early and often throughout the lifespan. In C. L. M. Keyes (Ed.), Mental well-being: International contributions to the study of positive mental health (p. 3-28). Springer Science + Business Media. https://doi.org/10.1007/978-94-007-51958_1

Khatimah, H. (2015). Gambaran school wellbeing pada peserta didik program kelas akselerasi di SMA Negeri 8 Yogyakarta. Psikopedagogia: Jurnal Bimbingan dan Konseling, 4(1), 20. https://doi.org/ 10.12928/psikopedagogia.v4i1.4485

Kirkcaldy, B. (Ed.). (2015). Promoting psychological wellbeing in children and families. UK: Palgrave Macmillan. https://doi.org/10.1057 /9781137479969

Konu, A., \& Rimpella, M. (2002). Well-being in schools: A conceptual model. Health Promotion International, 17(1), 79-87. https://doi.org/10.1093/heapro/17.1.79

Krauss, M. W., Seltzer, M. M., \& Jacobson, H. T. (2005). Adults with autism living at home or in non-family settings: Positive and negative aspects of residential status. Journal of Intellectual Disability Research, 49(2), 111-124. https://doi.org/10.1111/j.1365-2788. 2004.00599.x

Lester, L., \& Cross, D. (2015). The Relationship between school climate and mental and emotional wellbeing over the transition from primary to secondary school. Psychology of Well-Being, 5(1). https:// doi.org/10.1186/s13612-0150037-8

MacLeod, C., \& Fraser, B. J. (2010). Development, validation and application of a modified Arabic translation of the What Is Happening In this Class? (WIHIC) questionnaire. Learning Environments Research, 13(2), 105-125. https://doi.org/ 10.1007/s10984-0089052-5

Mungure, D. M. (2017). An Investigation of the teaching approach used by tutors to prepare science and mathematics teachers during training at Morogoro Teachers' College. Journal of Education and Practice, 8(6), 68-71. Diakses dari https://eric.ed.gov/?id=EJ1133089

O'Brien-Richardson, P. (2019). Hair harassment in urban schools and how it shapes the physical activity of black adolescent girls. The Urban Review, 51(3), 523-534. https://doi.org/10.1007/s11256-01900500-x

Powell, M. A., \& Graham, A. (2017). Wellbeing in schools: Examining the policy-practice nexus. The Australian Educational Researcher, 44(2), 213-231. https://doi.org /10.1007/s13384-0160222-7

Prabowo, A. (2016). Kesejahteraan psikologis remaja di sekolah. Jurnal Ilmiah Psikologi Terapan, 04(2), 246-260. https://doi.org/10.22219/jipt.v4i2.3527

Ryan, R. (2009). Self-determination theory and wellbeing. Research Review, 1, 1-2. Diakses dari http://www.bath.ac.uk/soc- 
pol/welldev/wed-new/network/researchreview/Review_1_Ryan.pdf

Salomone, E., Leadbitter, K., Aldred, C., Barrett, B., Byford, S., Charman, T., ... Slonims, V. (2018). The association between child and family characteristics and the mental health and wellbeing of caregivers of children with autism in midchildhood. Journal of Autism and Developmental Disorders, 48(4), 11891198. https://doi.org/10.1007/s10803-0173392-x

Sellwood, P. A. (1991). The investigative learning process. Journal of Design \& Technology Teaching, 24(1), 4-12. Diakses dari https://www.semanticscholar.org/paper/T he-Investigative-Learning-ProcessSellwood/c9fd0b2c53d1c3427f387bf9c3c dc247e 52d31b7

Soutter, A. K., Gilmore, A., \& O'Steen, B. (2010). How do high school youths' educational experiences relate to wellbeing? Towards a trans-disciplinary conceptualization. Journal of Happiness Studies, 12(4), 591-631. https://doi.org/ 10.1007/s10902-010-9219-5

Spilt, J. L., Koomen, H. M. Y., \& Thijs, J. T. (2011). Teacher wellbeing: The Importance of teacher-student relationships. Educational Psychology Review, 23(4), 457-477. https://doi.org/10.1007/s $10648 \quad-011$ 9170-y

Steptoe, A., O’Donnell, K., Marmot, M., \& Wardle, J. (2008). Positive affect and psychosocial processes related to health. British Journal of Psychology, 99(2), 211-227. https://doi.org/ 10.1111/j.20448295.2008.tb00474.x

Stewart-Brown S, Janmohamed K. (2008). Warwick-Edinburgh mental well-being scale (WEMWBS): User Guide, version 1. Diakses dari http://www.healthscotland.scot/health- topics/mental-health-andwellbeing/wemwbs

Taggart, F., Friede, T., Weich, S., Clarke, A., Johnson, M., \& Stewart-Brown, S. (2013). Cross cultural evaluation of the Warwick-Edinburgh mental well-being scale (WEMWBS)-A mixed methods study. Health and Quality of Life Outcomes, $\quad 11(1), \quad 2-12$. https://doi.org/10.1186/1477-7525-11-27

Tennant, R., Hiller, L., Fishwick, R., Platt, S., Joseph, S., Weich, S., ... Stewart-Brown, S. (2007). The Warwick-Edinburgh mental well-being scale (WEMWBS): Development and UK validation. Health and Quality of Life Outcomes, 5(1), 1-13. https://doi.org/10.1186/1477-7525-5-63

Van Petegem, K., Aelterman, A., Van Keer, H., \& Rosseel, Y. (2007). The influence of student characteristics and interpersonal teacher behaviour in the classroom on student's wellbeing. Social Indicators Research, 85(2), 279-291. https://doi.org/10.1007/s11205-007-90937

Weare, K. (2000). Promoting mental, emotional and social health: A whole school approach. London: Routledge. 